\title{
Mesorhizobium silamurunense sp. nov., isolated from root nodules of Astragalus species
}

\author{
Correspondence \\ Wen Xin Chen \\ wenxin@cau.edu.cn
}

\author{
Chun Tian Zhao, ${ }^{1,2}$ En Tao Wang, ${ }^{3}$ Yan Ming Zhang, ${ }^{1}$ Wen Feng Chen, ${ }^{1}$ \\ Xin Hua Sui, ${ }^{1}$ Wen Xin Chen, ${ }^{1}$ Hong Can Liu ${ }^{4}$ and Xiao Xia Zhang ${ }^{5}$
${ }^{1}$ State Key Laboratories for AgroBiotechnology/Department of Microbiology and Immunology, College of Biological Sciences, China Agricultural University, Beijing 100193, PR China Hangzhou 310014, PR China
${ }^{3}$ Departamento de Microbiología, Escuela Nacional de Ciencias Biológicas, Instituto Politécnico Nacional, México DF 11340, México
${ }^{4}$ Institute of Microbiology, Chinese Academy of Sciences, Beijing 100101, PR China
${ }^{5}$ Agricultural Cultural Collection of China, Institute of Agricultural Resources and Regional Planning, Chinese Academy of Agricultural Sciences, Beijing 100081, PR China \\ ${ }^{2}$ College of Biological and Environmental Engineering, Zhejiang University of Technology,
}

The genus Astragalus, comprising up to 2000 species of annual or perennial herbs, subshrubs and shrubs, is the largest genus in the plant family Fabaceae (Allen \& Allen, 1981), which is widely distributed in temperate regions of the world, principally in Asia, Europe and North America. In China, 401 species (221 endemic) have been recorded within this genus ( $\mathrm{Wu}$ et al., 2010), which are used as herbal medicine, forage, green manure, resources for honey

The GenBank/EMBL/DDBJ accession numbers for the partial rpoB gene sequences of strain CCBAU $01550^{\top}$, CCBAU 45265, CCBAU 25300 and CCBAU 45272, and are FJ393290-FJ393293, respectively. The GenBank/EMBL/DDBJ accession numbers for the partial 16S rRNA and nifH gene sequences of strain CCBAU 25300 are FJ824658 and FJ824661, respectively. The GenBank/EMBL/DDBJ accession number for the partial 16S rRNA gene sequence of strain CCBAU 45272 is FJ824659. The GenBank/EMBL/DDBJ accession numbers for the partial $r p o B$ gene sequences of other species of the genus Mesorhizobium are listed in the phylogenetic tree (Fig. 2d).

Three supplementary figures and a supplementary table are available with the online version of this paper. or gum production, ornamental plants, windbreaks and indicators of selenium and uranium contamination (Laguerre et al., 1997).

Approximately 90 species of the genus Astragalus have been recorded to form symbioses with root nodule bacteria (Allen \& Allen, 1981), which are mainly classified as four species: Mesorhizobium huakuii (Chen et al., 1991; Jarvis et al., 1997), Mezorhizobium septentrionale, Mezorhizobium temperatum (Gao et al., 2004), and Rhizobium loessense (Wei et al., 2003). The genus Mesorhizobium (Jarvis et al., 1997) belongs to the Alphaproteobacteria and at the time of writing consisted of 22 species with validly published names, including the recently described species: Mesorhizobium alhagi (Chen et al., 2010), Mesorhizobium robiniae (Zhou et al., 2010) and Mesorhizobium camelthorni (Chen et al., 2011).

In our previous study, diverse genomic species of the rhizobia associated with Astragalus species grown in the temperate regions of China were identified, and included a novel group, Mesorhizobium sp. I, of 29 strains isolated 
from the root nodules of Astragalus membranaceus and Astragalus adsurgens (Zhao et al., 2008). To determine their taxonomic status, four representative strains were further analysed in the present study and compared with reference strains of defined species by phenotypic, genotypic, phylogenetic and symbiotic characterizations.

The four representative strains (Table 1) of Mesorhizobium sp. I, CCBAU $01550^{\mathrm{T}}$, CCBAU 45265, CCBAU 45272 and CCBAU 25300, were isolated from root nodules of Astragalus membranaceus and Astragalus adsurgens growing in Inner Mongolia, Henan and Shandong provinces, which are located along the Yellow River in China (Zhao et al., 2008). All strains were maintained on yeast mannitol agar (YMA) slants at $4{ }^{\circ} \mathrm{C}$ for temporary storage or in $20 \%(\mathrm{w} / \mathrm{v})$ glycerol at $-80{ }^{\circ} \mathrm{C}$ for long-term storage. Unless otherwise indicated, strains were incubated at $28{ }^{\circ} \mathrm{C}$ for experiments in this study.

The almost complete full-length 16S rRNA gene sequences (about $1350 \mathrm{bp}$ ) were amplified by PCR and sequenced directly by using universal primers $\mathrm{P} 1$ and $\mathrm{P} 6$ according to Tan et al. (1997). The corresponding sequences of type strains of the recognised species of the genus Mesorhizobium were retrieved from the GenBank database. Multiple nucleotide sequence alignments were generated by using the CLUSTAL W program in the MEGA 4.0.2 software package (Tamura et al., 2007). Phylogenetic trees were constructed with MEGA version 4.0.2 software using the neighbourjoining (NJ) method with the Jukes-Cantor model (Jukes \& Cantor, 1969), and the maximum-parsimony (MP) method. Bootstrap analysis was based on 1000 replicates to validate the reliability of the branching pattern of the trees. The four representative strains had identical $16 \mathrm{~S}$ rRNA gene sequences and were closely related to Mesorhizobium plurifarium LMG
$11892^{\mathrm{T}}$ (99.8\% gene sequence similarity) with $92 \%$ bootstrap support, and shared $98.1 \% 16 \mathrm{~S}$ gene sequence similarity with Mezorhizobium loti LMG $6125^{\mathrm{T}}$, the type species of the genus Mesorhizobium (Fig. 1). The neighbour-joining tree and maximum-parsimony tree (not shown) had similar topologies.

The phylogenetic relationships of the four representative strains to recognized species of the genus Mesorhizobium were confirmed by sequencing analysis of the housekeeping genes atpD (ATP synthase, beta subunit), recA (recombinase A), glnII (glutamine synthetase type II) and $r p o B$ (RNA polymerase, beta subunit), which are frequently used as alternative phylogenetic markers within rhizobia (Gaunt et al., 2001; Martens et al., 2007; Martens et al., 2008; Turner \& Young, 2000). Partial $a t p D$, recA and glnII gene sequences were amplified and sequenced in our previous study (Zhao et al., 2008) with primer pairs atpD255F/ atpD782R, recA41F/recA640R and glnII12F/glnII689R, respectively (the primer coordinates correspond to Bradyrhizobium japonicum USDA110 gene positions), using previously reported protocols (Vinuesa et al., 2005). PCR amplification and sequencing of partial $r p o B$ gene sequences were performed with primers ropB82F ( $5^{\prime}$-AAC CTC ATC GAG GTT CAG AAG GC-3') and ropB1580R (5'-TGG TCC ATG AAC TGC GAG AGC TG-3'), corresponding to the $r p o B$ gene sequence of Sinorhizobium meliloti 1021 (GenBank/EMBL/DDBJ accession number AL591688) (Capela et al., 2001). Phylogenetic analyses were performed with the MEGA 4.0.2 software package (Tamura et al., 2007) using the neighbour-joining method with Kimura's two-parameter model and 1000 bootstrap replications. The four representative strains had identical $\mathrm{rec} A$ gene sequences and were most similar to M. plurifarium USDA $4413^{\mathrm{T}}$ with $93.3 \%$ gene sequence similarity. $r p o B$ gene sequences for the four

Table 1. Strains used in this study

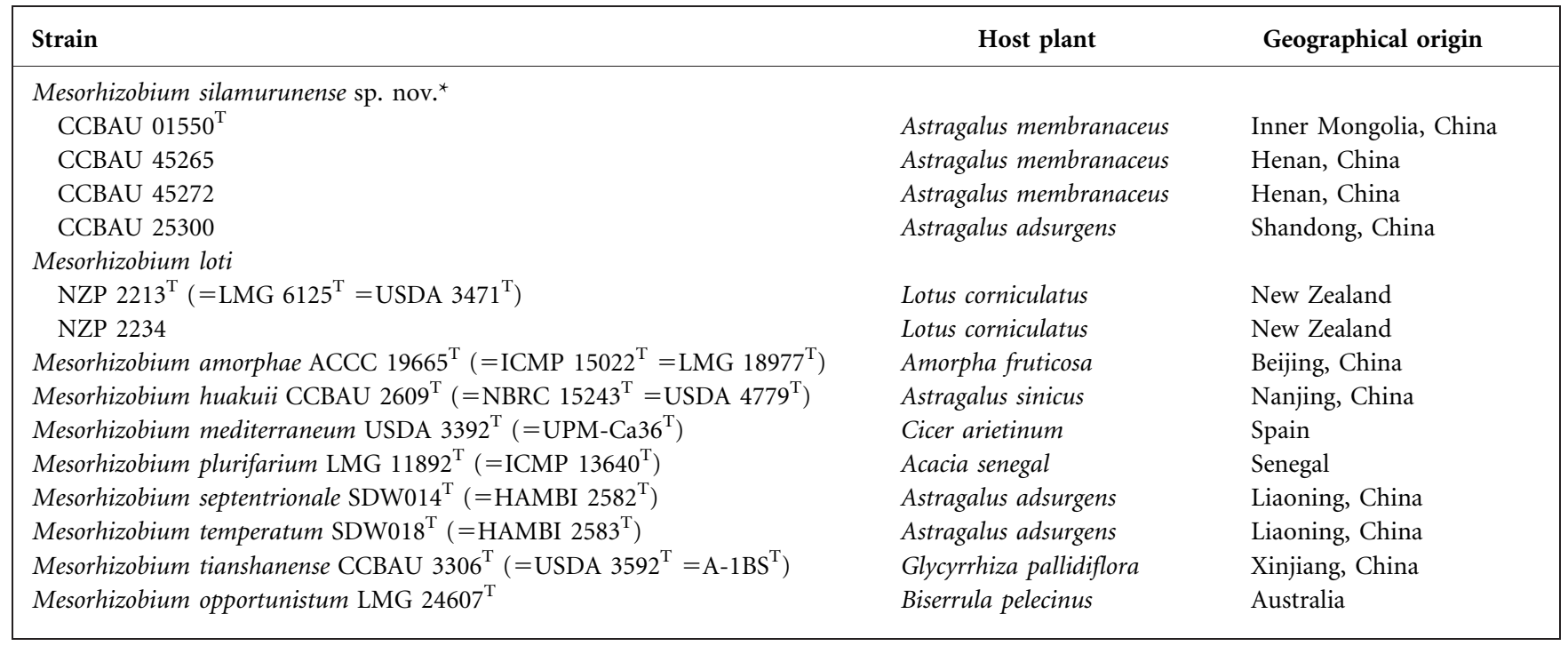

*These four strains represent a novel group containing 29 strains. 


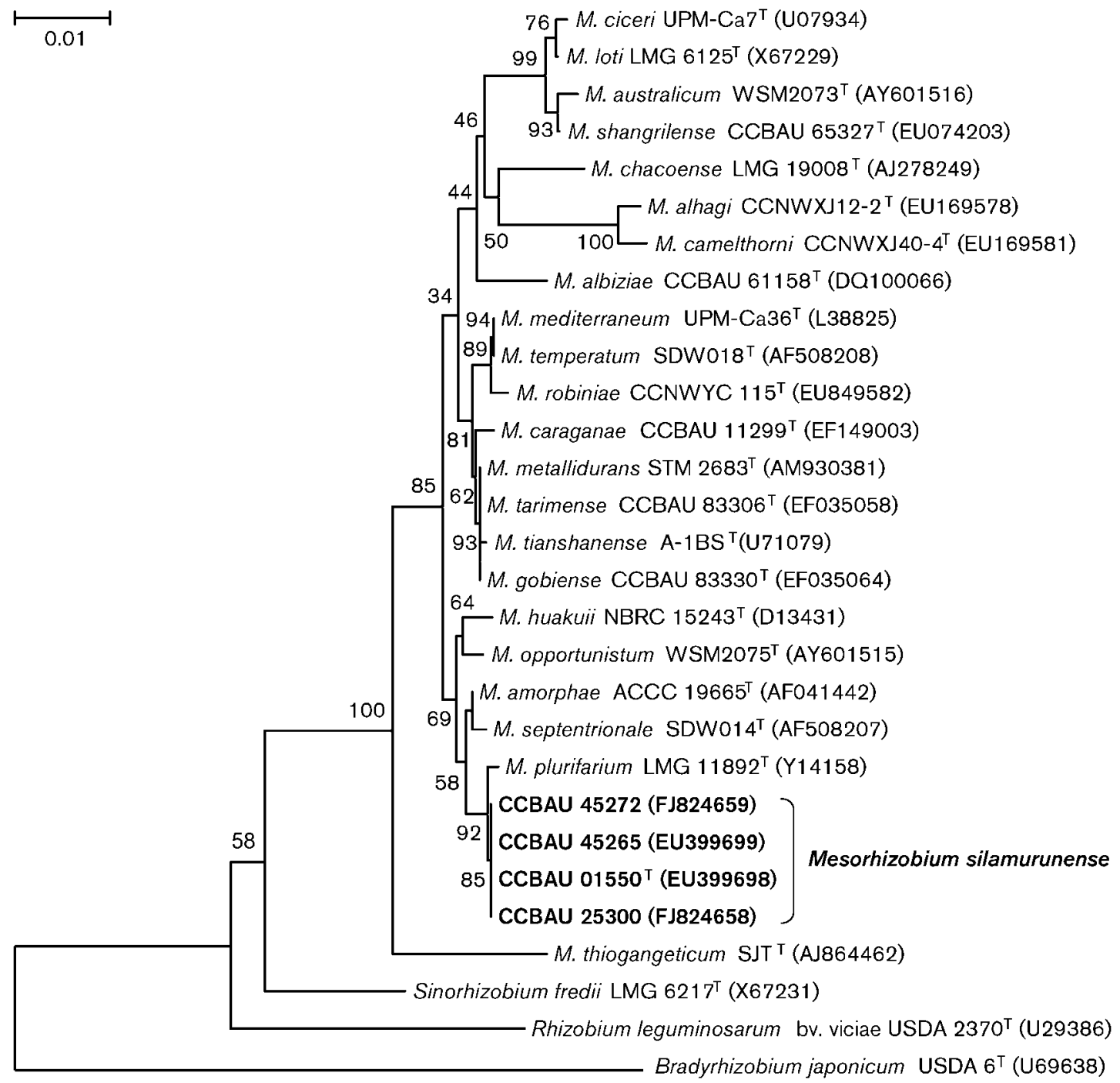

Fig. 1. Neighbour-joining tree based on sequence distance matrix (Jukes-Cantor) of 16S rRNA gene sequences showing the relationships among Mesorhizobium silamurunense sp. nov. and recognized species of the genus Mesorhizobium. Bootstrap confidence levels are indicated at the nodes. Bar, 0.01 expected changes per site.

representative strains were also identical and most similar to M. plurifarium LMG $11892^{\mathrm{T}}$ with $95.7 \%$ gene sequence similarity. The four strains had almost identical sequences for a $487 \mathrm{bp}$ intragenic fragment of the atpD gene and a 590 bp internal region of the $g \ln I I$ gene. They were also most similar to $M$. plurifarium strains ICMP $13640^{\mathrm{T}}$ and LMG $11892^{\mathrm{T}}$ respectively, with $93.8 \%$ and $93.6 \%$ sequence similarity for atpD and glnII genes, respectively (Fig. 2). The phylogenetic relationships based on the four housekeeping gene sequences were consistent with that obtained for $16 \mathrm{~S}$ rRNA gene sequences.

Three representative strains of the novel group (CCBAU $01550^{\mathrm{T}}$, CCBAU 45272 and CCBAU 45265) and the type strains of eight closely related species of the genus Mesorhizobium were subjected to SDS-PAGE analysis of whole-cell soluble proteins as described previously (Tan et al., 1997).
Digitization, normalization and numerical analyses of the protein profiles were performed with GelCompar II version 4.5 software (Applied Maths). The similarity of protein patterns between strain pairs was expressed by Pearson's coefficient and a UPGMA dendrogram was constructed (Vauterin \& Vauterin, 1992). Strains CCBAU $01550^{\mathrm{T}}$, CCBAU 45272 and CCBAU 45265 formed a cluster with strikingly similar protein patterns, indicating their considerable homogeneity, but they were significantly different from the protein profiles of related species of the genus Mesorhizobium (Fig. S1 available in IJSEM Online). These results also demonstrated that strains CCBAU $01550^{\mathrm{T}}$, CCBAU 45272 and CCBAU 45265 were not clones.

Analysis of cellular fatty acids is a useful method to characterize and identify microbes, especially in the study 

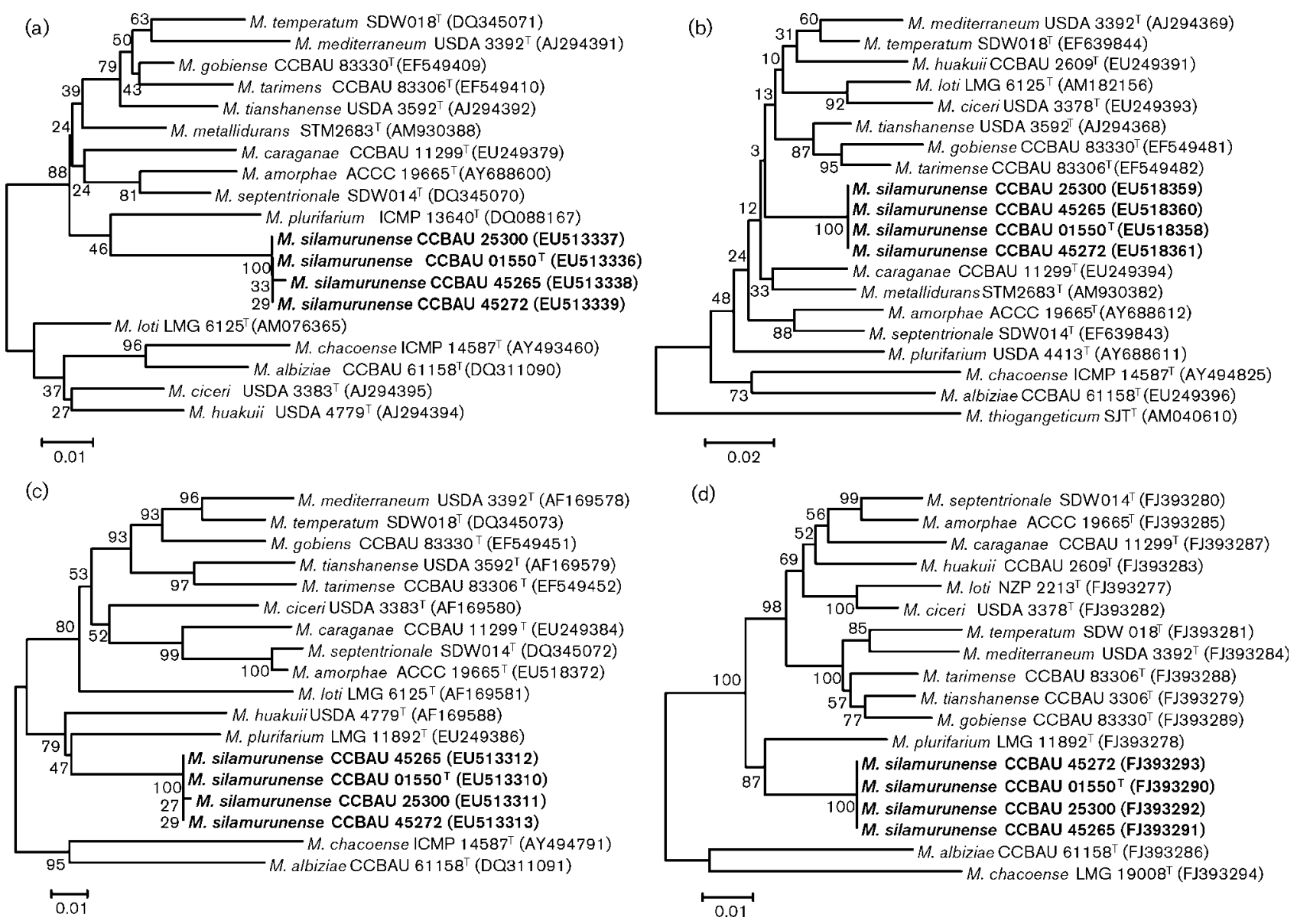

Fig. 2. Comparison of $\operatorname{atp} D(\mathrm{a}), \operatorname{rec} A(\mathrm{~b}), g \ln / l$ (c) and $r p o B$ (d) gene phylogenies, showing the relationships among Mesorhizobium silamurunense sp. nov. and recognized species of the genus Mesorhizobium. Trees were constructed by the neighbour-joining method with a Kimura two-parameter distance matrix. Bootstrap values (\%) are based on 1000 replicates and are shown at each node. Bars, 0.01 (a, c, d) or 0.02 (b) expected changes per site.

of species of the genus Mesorhizobium (Schutter \& Dick, 2000; Tighe et al., 2000). For analysis of cellular fatty acids, strains were grown on YMA medium ( $\mathrm{pH}$ 7.0) (Vincent, 1970 ) at $28^{\circ} \mathrm{C}$. Cells of the tested strains in the stationary growth phase were harvested and approximately $40 \mathrm{mg}$ were used for the preparation and extraction of fatty acid methyl esters according to methods described by Sasser (1990). Identification of these fatty acid methyl esters was completed with the MIDI Sherlock Microbial Identification System version 6.0 using the TSBA6 database for identification of the peaks. The comparison of fatty acid profiles between strain CCBAU $01550^{\mathrm{T}}$ and six related species of the genus Mesorhizobium (M. loti NZP 2234, M. plurifarium LMG $11892^{\mathrm{T}}$, M. huakuii CCBAU $2609^{\mathrm{T}}$, M. septentrionale SDW014 ${ }^{\mathrm{T}}, M$. amorphae ACCC $19665^{\mathrm{T}}$ and M. opportunistum LMG $24607^{\mathrm{T}}$ ) is shown in Table S1. Strain CCBAU $01550^{\mathrm{T}}$ could be assigned to the genus Mesorhizobium because it lacked $20: 3 \omega 6,9,12 c$ and summed feature 2 (12: 0, unknown ECL 10.928, 16: 1 iso I and/or 14:0 3-OH), but contained 17:0 iso fatty acids (Tighe et al., 2000). Furthermore, strain CCBAU $01550^{\mathrm{T}}$ had a distinctly different fatty acid profile compared to the other recognized species of the genus Mesorhizobium (Table S1).

DNA-DNA hybridization was performed using the spectrophotometric method (De Ley, 1970). The DNA G+C content was measured using the thermal denaturation $\left(T_{\mathrm{m}}\right)$ method of Marmur \& Doty (1962) using Escherichia coli K12 as the standard. The DNA G $+\mathrm{C}$ content of strain CCBAU $01550^{\mathrm{T}}$ was $62.4 \mathrm{~mol} \%$, which was within the range reported for the genus Mesorhizobium (59-64 mol\%) (Jarvis et al., 1997). DNA-DNA relatedness was greater than $80 \%$ among the representative strains of the novel group and ranged from 12.4 to $38.5 \%$ between CCBAU $01550^{\mathrm{T}}$ and the type strains of related species of the genus Mesorhizobium (Table 2). Taking the recommended species threshold of $70 \%$ DNADNA relatedness (Graham et al., 1991; Wayne et al., 1987), these results indicated that the novel group should be considered as a novel species in the genus of Mesorhizobium.

Phenotypic characteristics of CCBAU $01550^{\mathrm{T}}$, CCBAU 45265 , CCBAU 45272 and CCBAU 25300 and the type strains of closely related species of the genus were determined and 
Table 2. DNA-DNA relatedness (\%) between strain CCBAU $01550^{\top}$ and the type strains of related species of the genus Mesorhizobium

\begin{tabular}{|lc|}
\hline Strain & $\begin{array}{c}\text { DNA-DNA relatedness (\%) } \\
\text { with CCBAU 01550 }\end{array}$ \\
\hline CCBAU 45265 & 84.1 \\
CCBAU 45272 & 85.4 \\
M. plurifarium LMG $11892^{\mathrm{T}}$ & 38.5 \\
M. loti NZP 2213 & 19.3 \\
M. septentrionale SDW014 & Th \\
M. amorphae ACCC $19665^{\mathrm{T}}$ & 38.2 \\
M. temperatum SDW018 & 32.3 \\
M. huakuii CCBAU $2609^{\mathrm{T}}$ & 38.0 \\
M. mediterraneum USDA $3392^{\mathrm{T}}$ & 28.5 \\
M. tianshanense CCBAU $3306^{\mathrm{T}}$ & 23.8 \\
& 12.4 \\
\hline
\end{tabular}

compared according to the method described by Gao et al. (1994). The tested features included the utilization of sole carbon and nitrogen sources; resistance to antibiotics and dyes; and the ranges of $\mathrm{NaCl}$ concentration, $\mathrm{pH}$ and temperature for growth (Gao et al., 1994). Biochemical tests including catalase and oxidase production; methyl red and Voges-Proskauer reactions; and hydrolysis of casein, gelatin, starch, DNA and Tween 80 were performed according to Smibert \& Krieg (1994). Production of hydrogen sulfide from cysteine, and production of indole from tryptophan were examined as described by Barrow \& Feltham (2003). The results demonstrated that the novel group could be distinguished from related species of the genus Mesorhizobium by a combination of phenotypic characteristics, such as growth at $\mathrm{pH} 10.0$, but not in $1 \%$ $(\mathrm{w} / \mathrm{v}) \mathrm{NaCl}$; utilization of glucose, D-mannose, D-fructose, melibiose, D-glutamic acid, L-phenylalanine and L-valine, but not $\mathrm{D}$-arabinose raffinose, $\mathrm{DL}$-asparagine, and L-arginine; resistance to $\left(\mu \mathrm{g} \mathrm{ml}^{-1}\right)$ ampicillin (5), erythromycin (100) and Congo red (0.1), but sensitivity to kanamycin (50), streptomycin (5), bromothymol blue (0.1) and erythrosine bluish (0.1) (Table 3). Additional features are presented in the species description. In the cluster analysis based upon phenotypic features, strain CCBAU $01550^{\mathrm{T}}$ was clearly separated from the type strains of related species of the genus Mesorhizobium (Fig. S3).

The symbiotic genes (nod and nif) are required for the successful establishment of highly specific symbiosis between rhizobia and legumes. Partial nodC (931 bp) and nifH (784 bp) gene fragments were amplified with the primer pairs nodCF/nodCI and nifHF/nifHI, respectively, using protocols described by Laguerre et al. (2001). Neighbourjoining trees were constructed with the same methods used for the housekeeping gene analyses. In the phylogenetic tree based on nodC gene sequences, strains CCBAU $01550^{\mathrm{T}}$, CCBAU 45272, CCBAU 45265 and CCBAU 25300 formed a cluster sharing sequence similarities from $99.1 \%$ to $100 \%$. They were most similar to M. septentrionale SDW014 ${ }^{\mathrm{T}}(99.3 \%$ sequence similarity) (Fig. S2a). In the phylogenetic tree based
Table 3. Differential phenotypic characteristics of strains of Mesorhizobium silamurunense sp. nov. and closely related species of the genus Mesorhizobium

Strains: 1 , CCBAU $01550^{\mathrm{T}} ; 2$, CCBAU 25300; 3, CCBAU 45265; 4, CCBAU 45272; 5, M. plurifarium LMG $11892^{\mathrm{T}} ;$; 6, M. septentrionale SDW014 ${ }^{\mathrm{T}} ; 7$, M. amorphae ACCC $19665^{\mathrm{T}} ; 8$, M. huakuii CCBAU $2609^{\mathrm{T}} ; 9$, M. tianshanense CCBAU $3306^{\mathrm{T}}$. +, Growth or resistant; -, no growth or sensitive.

\begin{tabular}{|c|c|c|c|c|c|c|c|c|c|}
\hline Characteristic & 1 & 2 & 3 & 4 & 5 & 6 & 7 & 8 & 9 \\
\hline \multicolumn{10}{|l|}{ Growth at: } \\
\hline $\mathrm{NaCl}(1 \%)$ & - & - & - & - & + & - & - & + & - \\
\hline $\mathrm{pH} 10.0$ & + & + & + & + & + & - & - & + & + \\
\hline \multicolumn{10}{|l|}{ Sole carbon source } \\
\hline Glucose & + & + & + & + & + & - & + & + & + \\
\hline D-Arabinose & - & - & - & - & + & - & - & + & + \\
\hline D-Mannose & + & + & + & + & + & + & - & + & - \\
\hline D-Fructose & + & + & + & + & + & - & + & + & + \\
\hline Melibiose & + & + & + & + & + & - & + & + & + \\
\hline Raffinose & - & - & - & - & + & + & + & + & - \\
\hline D-Xylose & + & + & + & + & + & - & + & + & + \\
\hline Sorbose & - & - & - & - & + & - & - & - & - \\
\hline Inulin & - & + & + & - & + & + & - & - & - \\
\hline Sodium acetate & + & + & + & - & + & - & - & + & - \\
\hline Sodium citrate & - & - & - & - & + & - & + & - & + \\
\hline Sodium pyruvate & - & - & - & - & + & - & - & + & + \\
\hline Sodium sorbate & + & + & + & + & + & + & - & + & - \\
\hline DL-Sodium malate & + & + & + & + & + & - & + & + & + \\
\hline Galactitol & + & + & + & - & - & - & - & - & - \\
\hline meso-Erythritol & + & + & + & - & - & - & + & - & + \\
\hline Lactose & - & - & - & - & + & - & - & + & + \\
\hline \multicolumn{10}{|l|}{ Sole nitrogen source } \\
\hline L-Aspartic acid & + & + & + & - & + & - & - & + & - \\
\hline D-Glutamic acid & + & + & + & + & + & - & - & + & - \\
\hline L-Phenylalanine & + & + & + & + & + & - & - & + & - \\
\hline L-Valine & + & + & + & + & + & + & - & + & - \\
\hline \multicolumn{10}{|l|}{ Resistance to $\left(\mu \mathrm{g} \mathrm{ml}^{-1}\right)$ : } \\
\hline Ampicillin (5) & + & + & + & + & + & - & - & - & + \\
\hline Kanamycin sulfate $(50)$ & - & - & - & - & + & - & - & + & - \\
\hline Streptomycin sulfate (5) & - & - & - & - & + & - & - & + & - \\
\hline Erythromycin (100) & + & + & + & + & + & - & - & + & + \\
\hline Chloramphenicol (5) & - & + & - & + & - & - & + & + & + \\
\hline \multicolumn{10}{|l|}{ Tolerance of $(\%)$ : } \\
\hline Bromothymol blue (0.1) & - & - & - & - & + & - & - & - & - \\
\hline Congo red $(0.1)$ & + & + & + & + & + & + & + & + & - \\
\hline Erythrosine bluish (0.1) & - & - & - & - & + & - & - & - & - \\
\hline Sodium deoxycholate $(0.1)$ & + & + & - & + & + & - & - & + & - \\
\hline
\end{tabular}

on nifH gene sequences, the four novel strains were divided into three lineages (Fig. S2b): 1, strain CCBAU 45265 and CCBAU 45272 sharing $100 \%$ sequence similarity; 2, strain CCBAU $01550^{\mathrm{T}}$ and $M$. septentrionale SDW014 ${ }^{\mathrm{T}}$ sharing $97.2 \%$ nifH gene sequence similarity; and 3, strain CCBAU 25300 sharing $90.9 \%$ and $93.3 \%$ nifH gene sequence similarity with the former two lineages, respectively. These results demonstrated that nod genes in the strains of the novel species may have the same origin, but nif genes may have 
divergent origins, possibly via lateral gene transfer as reported by Sullivan \& Ronson (1998).

Host range is an important feature of root-nodule bacteria. Cross-nodulation tests were performed for strain CCBAU $01550^{\mathrm{T}}$ with the original plant (Astragalus membranaceus) and the other selected leguminous plants including Astragalus adsurgens, Glycine max, Pisum sativum, Phaseolus vulgaris, Vigna radiate, Medicago sativa, Lotus corniculatus, Trifolium repens, Caragana intermedia, Lespedeza cunecta and Leucaena leucocephala. The seeds of the leguminous plants were surface-sterilized, germinated and inoculated according to a standard procedure (Vincent, 1970). The inoculated seedlings were grown in Gibson tubes supplied with a nitrogen-free plant nutrient solution (Brunel et al., 1996), while noninoculated plants were used as controls. Three replicates were prepared for each treatment. Plants were incubated in a greenhouse under natural sunlight. After 45-60 days, the plants were harvested and nodules were examined. Strain CCBAU $01550^{\mathrm{T}}$ formed pink root nodules on Astragalus membranaceus, Astragalus adsurgens and Caragana intermedia, indicating that the nodules were effective for nitrogen fixation. White (ineffective) nodules were found on Phaseolus vulgaris inoculated with CCBAU $01550^{\mathrm{T}}$. No nodules were found on Glycine max, Pisum sativum, Vigna radiate, Medicago sativa, Lotus corniculatus, Trifolium repens, Lespedeza cunecta or Leucaena leucocephala inoculated with CCBAU $01550^{\mathrm{T}}$, or on non-inoculated control plants.

The differences in the phenotypic and genotypic characteristics of strains of the novel group indicated that they represented a novel species within the genus Mesorhizobium, for which the name Mesorhizobium silamurunense sp. nov. is proposed.

\section{Description of Mesorhizobium silamurunense sp. nov.}

Mesorhizobium silamurunense [si.la.mu.ru.nen'se. N.L. neut. adj. silamurunense of or belonging to silamurun (Yellow River in Mongolian), referring to the original isolation of this bacteria from the Yellow River valley].

Cells are Gram-negative, aerobic, motile, non-spore-forming rods, $1.2-1.8 \mu \mathrm{m}$ wide by $2.1-4.2 \mu \mathrm{m}$ long. Colonies on YMA plates are circular, convex, white and opaque, usually 1-2 $\mathrm{mm}$ in diameter within 5-7 days of incubation at $28{ }^{\circ} \mathrm{C}$. The optimum temperature and $\mathrm{pH}$ for growth are $28{ }^{\circ} \mathrm{C}$ and $\mathrm{pH} 7$, respectively. The maximum temperature for growth is $40{ }^{\circ} \mathrm{C}$. Able to survive being heated at $60{ }^{\circ} \mathrm{C}$ for $10 \mathrm{~min}$. Positive result in tests for catalase, indole production, hydrolysis of DNA, and litmus milk acid production, acid coagulation and peptonization. The ability to hydrolyse DNA varies among the novel isolates; strain CCBAU 45272 shows the highest DNA hydrolysis activity. Negative result in tests for oxidase, urease, nitrate reductase, L-phenylalanine deaminase, 3-ketolactose, $\mathrm{H}_{2} \mathrm{~S}$ production, and hydrolysis of starch, gelatin and Tween 80 . Reduces litmus milk, methylene blue and Nile blue, but methyl red and Voges-Proskauer reactions are negative. Utilizes D-galactose, D-glucose, sucrose,
D-fructose, inositol, inulin (except strains CCBAU $01550^{\mathrm{T}}$ and CCBAU 45272), DL-sodium malate, galactitol (except CCBAU 45272), meso-erythritol (except CCBAU 45272), maltose, D-mannose, melibiose, L-rhamnose, sodium acetate (except CCBAU 45272), sodium succinate, D-sorbitol, trehalose and D-xylose as sole carbon sources for growth, but not adipic acid, D-amygdalin, D-arabinose, calcium gluconate, calcium malonate, dextrin, melezitose, sodium pyruvate, raffinose, lactose, salicin, sodium citrate, sodium formate, sodium D-gluconate, hippuric acid, sorbose, soluble starch, syringic acid, potassium sodium tartrate, L-arginine, DLasparagine, glycine, L-methionine and L-proline. Utilizes L-threonine, L- $\alpha$-aminopropionic acid, L-arginine, L-aspartic acid (except strain CCBAU 45272), L-cystine, D-glutamic acid, L-glutamic acid, hypoxanthine, L-isoleucine, L-lysine, L-phenylalanine and L-valine as sole nitrogen sources. Resistant to $\left(\mu \mathrm{g} \mathrm{ml}^{-1}\right)$ erythromycin (100), ampicillin (5), kanamycin sulfate (5), neomycin sulfate (5) and gentamicin sulfate (5). Sensitive to $\left(\mu \mathrm{g} \mathrm{ml}^{-1}\right)$ streptomycin sulfate (5), tetracycline hydrochloride (5), ampicillin (50), chloramphenicol (50), kanamycin sulfate (50), neomycin sulfate (50), gentamicin sulfate (50) and erythromycin (300). Strains CCBAU $01550^{\mathrm{T}}$ and CCBAU 45265 are sensitive to chloramphenicol $(5 \mu \mathrm{g}$ $\mathrm{ml}^{-1}$ ), but strains CCBAU 25300 and CCBAU 45272 are resistant to it. Strains grow on YMA plates containing $0.1 \%$ (w/v) Congo red or sodium deoxycholate (except strain CCBAU 45265), but do not grow in $1 \%(\mathrm{w} / \mathrm{v}) \mathrm{NaCl}$ in YMA. Synthesizes the following fatty acids (full details in Table S1): 12:0 3-OH, 14:0, 13:0 iso $3-\mathrm{OH}$, summed feature $3(16: 1 \omega 7 c / 16: 1 \omega 6 c$ and/or $16: 1 \omega 6 c / 16: 1 \omega 7 c)$, $16: 0,17: 0$ iso, $17: 1 \omega 8 c, 17: 0$, summed feature $8(18: 1$ $\omega 7 c$ and/or $18: 1 \omega 6 c), 18: 0,19: 0$ cyclo $\omega 8 c$ and $20: 0$.

The type strain, CCBAU $01550^{\mathrm{T}}\left(=\right.$ HAMBI $3029^{\mathrm{T}}=\mathrm{LMG}$ $24822^{\mathrm{T}}$ ), was isolated from the root nodules of Astragalus membranaceus collected from Inner Mongolia, China. The DNA G + C content of the type strain is $62.4 \mathrm{~mol} \%\left(T_{\mathrm{m}}\right)$.

\section{Acknowledgements}

This work was financed by the National Natural Science Foundation of China (project no. 30870004 and 30970004), Chinese Universities Scientific Fund (No. 2009JD19) and National Basic Research Program of China (2010CB126500). We thank Professor Martha E. Trujillo (Universidad de Salamanca, Spain) for providing thoughtful and constructive comments on the manuscript.

\section{References}

Allen, O. N. \& Allen, E. K. (1981). The Leguminosae: A Source Book of Characteristics, Uses, and Nodulation. Madison, WI: University of Wisconsin Press.

Barrow, G. I. \& Feltham, R. K. A. (2003). Cowan and Steel's Manual for the Identification of Medical Bacteria, 3rd edn. Cambridge: Cambridge University Press.

Brunel, B., Rome, S., Ziani, R. \& Cleyet-Marel, J. C. (1996). Comparison of nucleotide diversity and symbiotic properties of Rhizobium meliloti populations from annual Medicago species. FEMS Microbiol Ecol 19, 71-82. 
Capela, D., Barloy-Hubler, F., Gouzy, J., Bothe, G., Ampe, F., Batut, J., Boistard, P., Becker, A., Boutry, M. \& other authors (2001). Analysis of the chromosome sequence of the legume symbiont Sinorhizobium meliloti strain 1021. Proc Natl Acad Sci U S A 98, 9877-9882.

Chen, W. X., Li, G. S., Qi, Y. L., Wang, E. T., Yuan, H. L. \& Li, J. L. (1991). Rhizobium huakuii sp. nov., isolated from the root nodules of Astragalus sinicus. Int J Syst Bacteriol 41, 275-280.

Chen, W. M., Zhu, W. F., Bontemps, C., Young, J. P. \& Wei, G. H. (2010). Mesorhizobium alhagi sp. nov., isolated from wild Alhagi sparsifolia in north-western China. Int J Syst Evol Microbiol 60, 958962.

Chen, W. M., Zhu, W. F., Bontemps, C., Young, J. P. \& Wei, G. H. (2011). Mesorhizobium camelthorni sp. nov., isolated from Alhagi sparsifolia. Int J Syst Evol Microbiol 61, 574-579.

De Ley, J. (1970). Reexamination of the association between melting point, buoyant density, and chemical base composition of deoxyribonucleic acid. J Bacteriol 101, 738-754.

Gao, J. L., Sun, J. G., Li, Y., Wang, E. T. \& Chen, W. X. (1994). Numerical taxonomy and DNA relatedness of tropical rhizobia isolated from Hainan province, China. Int J Syst Bacteriol 44, 151-158.

Gao, J. L., Turner, S. L., Kan, F. L., Wang, E. T., Tan, Z. Y., Qiu, Y. H., Gu, J., Terefework, Z., Young, J. P. \& other authors (2004). Mesorhizobium septentrionale sp. nov. and Mesorhizobium temperatum sp. nov., isolated from Astragalus adsurgens growing in the northern regions of China. Int J Syst Evol Microbiol 54, 2003-2012.

Gaunt, M. W., Turner, S. L., Rigottier-Gois, L., Lloyd-Macgilp, S. A. \& Young, J. P. (2001). Phylogenies of atpD and recA support the small subunit rRNA-based classification of rhizobia. Int J Syst Evol Microbiol 51, 2037-2048.

Graham, P. H., Sadowsky, M. J., Keyser, H. H., Barnet, Y. M., Bradley, R. S., Cooper, J. E., DeLey, D. J. D., Jarvis, B. D. W., Roslycky, E. B. \& other authors (1991). Proposed minimal standards for the description of new genera and species of root- and stem-nodulating bacteria. Int J Syst Bacteriol 41, 582-587.

Jarvis, B. D. W., van Berkum, P., Chen, W. X., Nour, S. M., Fernandez, M. P., Cleyet-Marel, J. C. \& Gillis, M. (1997). Transfer of Rhizobium loti, Rhizobium huakuii, Rhizobium ciceri, Rhizobium mediterraneum, and Rhizobium tianshanense to Mesorhizobium gen. nov. Int J Syst Bacteriol 47, 895-898.

Jukes, T. H. \& Cantor, C. R. (1969). Evolution of protein molecules. In Mammalian Protein Metabolism, vol. 3, pp. 21-132. Edited by H. N. Munro. New York: Academic Press.

Laguerre, G., van Berkum, P., Amarger, N. \& Prévost, D. (1997). Genetic diversity of rhizobial symbionts isolated from legume species within the genera Astragalus, Oxytropis, and Onobrychis. Appl Environ Microbiol 63, 4748-4758.

Laguerre, G., Nour, S. M., Macheret, V., Sanjuan, J., Drouin, P. \& Amarger, N. (2001). Classification of rhizobia based on nodC and nifH gene analysis reveals a close phylogenetic relationship among Phaseolus vulgaris symbionts. Microbiology 147, 981-993.

Marmur, J. \& Doty, P. (1962). Determination of the base composition of deoxyribonucleic acid from its thermal denaturation temperature. J Mol Biol 5, 109-118.

Martens, M., Delaere, M., Coopman, R., De Vos, P., Gillis, M. \& Willems, A. (2007). Multilocus sequence analysis of Ensifer and related taxa. Int J Syst Evol Microbiol 57, 489-503.

Martens, M., Dawyndt, P., Coopman, R., Gillis, M., De Vos, P. \& Willems, A. (2008). Advantages of multilocus sequence analysis for taxonomic studies: a case study using 10 housekeeping genes in the genus Ensifer (including former Sinorhizobium). Int J Syst Evol Microbiol 58, 200-214.

Sasser, M. (1990). Identification of bacteria by gas chromatography of cellular fatty acids, MIDI Technical Note 101. Newark, DE: MIDI Inc.

Schutter, M. E. \& Dick, R. P. (2000). Comparison of fatty acid methyl ester (FAME) methods for characterizing microbial communities. Soil Sci Soc Am J 64, 1659-1668.

Smibert, R. M. \& Krieg, N. R. (1994). Phenotypic characterization. In Methods for General and Molecular Bacteriology, pp. 607-654. Edited by P. Gerhardt, R. G. E. Murray, W. A. Wood \& N. R. Krieg. Washington, DC: American Society for Microbiology.

Sullivan, J. T. \& Ronson, C. W. (1998). Evolution of rhizobia by acquisition of a $500-\mathrm{kb}$ symbiosis island that integrates into a phetRNA gene. Proc Natl Acad Sci U S A 95, 5145-5149.

Tamura, K., Dudley, J., Nei, M. \& Kumar, S. (2007). MEGA4: molecular evolutionary genetics analysis (MEGA) software version 4.0. Mol Biol Evol 24, 1596-1599.

Tan, Z. Y., Xu, X. D., Wang, E. T., Gao, J. L., Martinez-Romero, E. \& Chen, W. X. (1997). Phylogenetic and genetic relationships of Mesorhizobium tianshanense and related rhizobia. Int J Syst Bacteriol 47, 874-879.

Tighe, S. W., de Lajudie, P., Dipietro, K., Lindström, K., Nick, G. \& Jarvis, B. D. (2000). Analysis of cellular fatty acids and phenotypic relationships of Agrobacterium, Bradyrhizobium, Mesorhizobium, Rhizobium and Sinorhizobium species using the Sherlock Microbial Identification System. Int J Syst Evol Microbiol 50, 787-801.

Turner, S. L. \& Young, J. P. (2000). The glutamine synthetases of rhizobia: phylogenetics and evolutionary implications. Mol Biol Evol 17, 309-319.

Vauterin, L. \& Vauterin, P. (1992). Computer-aided objective comparison of electrophoresis patterns for grouping and identification of microorganisms. Eur Microbiol 1, 37-41.

Vincent, J. M. (1970). A Manual for the Practical Study of Root Nodule Bacteria. Oxford: Blackwell Scientific.

Vinuesa, P., Silva, C., Werner, D. \& Martínez-Romero, E. (2005). Population genetics and phylogenetic inference in bacterial molecular systematics: the roles of migration and recombination in Bradyrhizobium species cohesion and delineation. Mol Phylogenet Evol 34, 29-54.

Wayne, L. G., Brenner, D. J., Colwell, R. R., Grimont, P. A. D., Kandler, O., Krichevsky, M. I., Moore, L. H., Moore, W. E. C., Murray, R. G. E. \& other authors (1987). International Committee on Systematic Bacteriology. Report of the ad hoc committee on reconciliation of approaches to bacterial systematics. Int J Syst Bacteriol 37, 463-464.

Wei, G. H., Tan, Z. Y., Zhu, M. E., Wang, E. T., Han, S. Z. \& Chen, W. X. (2003). Characterization of rhizobia isolated from legume species within the genera Astragalus and Lespedeza grown in the Loess Plateau of China and description of Rhizobium loessense sp. nov. Int J Syst Evol Microbiol 53, 1575-1583.

Wu, Z. Y., Raven, P. H. \& Hong, D. Y. (editors) (2010). Flora of China. vol. 10, (Fabaceae). Beijing and St. Louis: Science Press and Missouri Botanical Garden Press.

Zhao, C. T., Wang, E. T., Chen, W. F. \& Chen, W. X. (2008). Diverse genomic species and evidences of symbiotic gene lateral transfer detected among the rhizobia associated with Astragalus species grown in the temperate regions of China. FEMS Microbiol Lett 286, 263-273.

Zhou, P. F., Chen, W. M. \& Wei, G. H. (2010). Mesorhizobium robiniae sp. nov., isolated from root nodules of Robinia pseudoacacia. Int J Syst Evol Microbiol 60, 2552-2556. 